\title{
The need for a protean fisheries science to address the degradation of exploited aquatic ecosystems
}

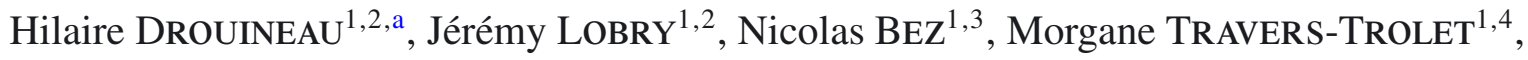 \\ Youen VERMARD ${ }^{1,5}$ and Didier GASCUEL ${ }^{1,6}$ \\ 1 Association Française d'Halieutique (AFH) \\ 2 Irstea, UR EABX, Centre de Bordeaux, 50 avenue de Verdun, 33612 Cestas Cedex, France \\ 3 UMR 212 EME, IRD (Institut de Recherche pour le Développement), 34200 Sète, France \\ 4 IFREMER, Laboratoire Ressources Halieutiques, 62321 Boulogne-sur-Mer, France \\ 5 IFREMER, Unit of Fisheries Ecology and Modelling, BP 21105, 44311 Nantes Cedex 03, France \\ ${ }^{6}$ Université Bretagne Loire (UBL), Agrocampus Ouest, UMR Ecologie et santé des écosystèmes, 65 route de SaintBrieuc, CS 84215, \\ 35042 Rennes, France
}

Received 24 May 2016; Accepted 30 June 2016

\begin{abstract}
In this introductory paper we highlight key questions that were discussed during the symposium on "Status, functioning and shifts in marine ecosystems" organized by the Association Française d'Halieutique (French Association for Fisheries Sciences, Montpellier, France, July 2015). This symposium illustrated that fisheries science is now working at multiple scales and on all dimensions of socio-ecosystems (ecological, political, sociological, and economic), with a great diversity of approaches and taking into account different levels of complexity while acknowledging diverse sources of uncertainty. We argue that we should go one step further and call for a protean fisheries science to address the deteriorated states of aquatic ecosystems caused by anthropogenic pressures. Protean science is constantly evolving to meet emerging issues, while improving its coherence and integration capacity in its complexity. This science must be nourished by multiple approaches and be capable of addressing all organizational scales, from individual fish or fishermen up to the entire ecosystem, include society, its economy and the services it derives from aquatic systems. Such a protean science is required to address the complexity of ecosystem functioning and of the impacts of anthropogenic pressures.
\end{abstract}

Keywords: EAFM / fisheries management / fisheries science / marine resources / models; uncertainty

\section{Introduction}

Fish provide $16.7 \%$ of animal protein for the global population and more than $20 \%$ of animal protein for 2.9 billion people (FAO 2014). The degradations of both structure and functioning of aquatic ecosystems due to overfishing, contamination, habitat fragmentation and degradation or water extraction are now widely recognised and documented (Postel and Richter 2003; Lotze et al. 2006; Worm et al. 2006; Chevillot et al. 2016; in this symposium: Brind'Amour et al.; Chevillot et al.; Kaimuddin et al.; Le Luherne et al.; Olmos et al.; Vogel et al.). Among the drivers of global change, climate change is a major threat for ecosystems affecting all biological scales (Gattuso et al. 2015): primary productivity, species distributions, and community and food web structure (Cheung et al. 2010). Modifications in primary production (Barange et al. 2010) and acidification due to carbon sequestration (Orr et al. 2005; Doney et al. 2009; Feely et al. 2009) potentially

a Corresponding author: hilaire.drouineau@irstea.fr have drastic consequences - although these remain largely unpredictable. These impacts on aquatic ecosystems and on the services they provide need to be investigated, and possibly minimized through appropriate management (Millennium Ecosystem Assessment 2005). In this context, the 12th symposium organised by the Association Française d'Halieutique (AFH, French Association for Fisheries Sciences) in 2015 illustrated that assessing the states of aquatic ecosystems and the effects of anthropogenic pressures acting at different spatial, temporal and biological scales, requires a protean science that considers simultaneously all scales, levels of complexity and dimension. This foreword does not aim to be an exhaustive analysis of upcoming challenges for fisheries sciences, but rather aims to highlight key questions that were discussed during the symposium that took place in Montpellier, France (July 1-3, 2015) on "Status, functioning and shifts in marine ecosystems". The oral presentations of this symposium are available at http://www.association-francaise-halieutique. $\mathrm{fr} /$ conferences. Four contributions are published in the present issue. 


\section{A science addressing all organizational scales}

Scales and their interactions are an important topic in ecology (Levin 1992; Chave 2013). The symposium illustrated current developments on three complementary scales.

\subsection{On the road to the ecosystem approach for fisheries?}

The ecosystem approach to fisheries management (EAFM) is a paradigm born in the early 2000s following, among others, the FAO code of conduct for responsible fisheries in 1995 and the Reykjavik conference in 2002 (Garcia 2003). Implementing a true EAFM was precisely at the core of the manifesto "A future for marine fisheries in Europe" published by the AFH in 2011 (Gascuel et al. 2011). The EAFM calls for a change from traditional single species fisheries management to management that considers all implications and dimensions of fishery socio-ecosystems: multispecies catches, bycatches, trophic implications, habitat degradation, socio-economic issues, governance, etc More than ten years after its creation, the EAFM is progressively being implemented. Through the modification of its working groups, the International Council for the Exploration of the Sea (ICES) is for example currently trying to regionalize its advice to provide regional ecosystem advice. Recently, a working group established by the Scientific Technical and Economic Committee for Fisheries (STECF) of the European Commission to work on the development of the EAFM in European seas, proposed methods to achieve integrated fleet-based management (Gascuel et al. 2012). Ecosystem impacts are also one of the main criteria considered in fisheries' ecolabels which have appeared since the 2000s. In this context, the discard ban implemented by the European Commission can be considered a new step within the EAFM.

Several tools have been developed to support the EAFM, from indicators to models. The indicators developed in the context of the Water Framework Directive (Hering et al. 2010) and the upcoming indicators from the Marine Strategy Framework Directive will operationalize long-term monitoring of marine aquatic ecosystem status, which is a cornerstone of biodiversity preservation and restoration. The next challenge is to move beyond monitoring structural diversity via the application of indicators of abundance and diversity by developing and applying indicators of functional diversity. In this paper, we call this functional diversity "ecodiversity" to avoid any confusion with biodiversity and structural diversity. Such indicators need to assess the ecological functions of ecosystems to inform on the quality of their functioning. We, the fisheries scientists attending the symposium, have direct responsibilities for characterizing the ecological status of several ecosystems and some of these case studies were presented during the 2015 symposium (Lucena-Frédou et al., this symposium; Lobry et al., this symposium; Wessel et al., this symposium; Laë et al., this symposium).

Trophic models such as Ecopath, Ecosim (Pauly et al. 2000) and Ecotroph (Gascuel and Pauly 2009) are now being applied to assess ecosystems worldwide to inform fisheries management (a list of applications can be found at EcoBase
http://sirs.agrocampus-ouest.fr/EcoBase/). Methods have been developed to evaluate the sensitivity of model results to uncertainty in parameters (Guesnet et al. 2015; Lobry et al., this symposium) and model structure (Prato et al. 2014, this symposium). In describing trophic cascades, these models have proven useful to inform management on the direct and indirect effects of fisheries and management throughout the food web. They have raised major strategic questions concerning fisheries, such as the recent debate concerning the socalled balanced harvesting approach (Garcia et al. 2015, 2012; Froese et al. in Press). During the symposium related questions were discussed in a dedicated debate on ecosystem management (Dagorn et al., this symposium). In the last decade, end-to-end models (Fulton 2010; Rose et al. 2010) such as Atlantis (Fulton et al. 2004) or Osmose (Shin and Cury 2004), have provided a more detailed description of ecosystem functioning by coupling physicochemical oceanographic descriptors with population dynamics for organisms ranging from microbes to higher trophic levels. Such integration of all ecosystem components and their interactions offers new opportunities to explore climate change effects or those of other anthropogenic stressors on ecosystems. These models have proven useful for informing management regarding major strategic fisheries management questions (Lehuta et al. 2016), such as when to fish, where to fish or which trophic levels to harvest. During the symposium several presentations highlighted the ability of trophic models to provide diagnostics of fishing impacts at the ecosystem scale for Mauritanian waters (Meissa et al., this symposium), Tunisian waters (Abdou et al. 2016) the Bay of Biscay and Celtic Sea (Moullec et al., this symposium), the Mediterranean Sea (Halouani et al., this symposium), and at a global scale (Colleter et al., this symposium). Other integrated models like ISIS-Fish (Lehuta et al., this symposium) or Atlantis (Girardin et al., this symposium) were shown in turn to be useful for analyzing the impacts of management decisions on the English Channel and the Bay of Biscay.

However, most available tools focus on the ecological part of socio-ecosystems, and there is a lack of tools for addressing the socio-economic context in which fisheries operate (Gascuel et al. 2012). The ecosystem services concept formulated during the Millenium Ecosystem Assessment (Millennium Ecosystem Assessment 2005) can be a tool to fill this gap (Vanhoutte-Brunier et al., this symposium). However operational tools are still scarce and should be considered carefully specifically for dealing with moral issues regarding the value of nature (Maris 2014, this symposium). Life Cycle Assessment could also prove useful in the future to assess the sustainability of sea food production in a more integrated way (Avadí and Fréon 2013; Fréon et al., this symposium), as could viability models which, instead of predicting precise system-trajectories, only predict bounds in which the system is expected to remain sustainable (Planque et al. 2014; this symposium).

\subsection{Population/species scale: still advancing}

The implementation of the EAFM does not mean that the traditional population scale is no longer considered, first of all because most stocks are still assessed using mono-specific 
models (e.g., Folliot et al., this symposium; Marandel et al. 2016). A better understanding of species' ecology and especially of species' diets is also crucial to achieve a better understanding of ecosystem functioning. For example, Tableau et al. (this symposium) assessed the influence of the availability of trophic resources on nursery grounds on juvenile abundance of certain species. Van Beveren et al. (this symposium) focused on the control exerted by Bluefin tuna on pelagic species through predator-prey relationships. Moreover, population-based approaches are useful for understanding climate change effects on population dynamics and the adaptability of species.

The coupling of population-based approaches and hydrodynamic oceanic models has proven useful for assessing the role of oceanic conditions on population dynamics and subsequently for exploring the consequences of climate change scenarios. Bertrand et al. (2011; this symposium) for example demonstrated the influence of oxygen concentrations on the distribution and abundance of various pelagic species on the Peruvian coast. At an individual level, the dynamic energy budget (DEB, Kooijman 2000) model has helped to discriminate between the reproductive strategies of sardine and anchovy (Gatti et al., this symposium). Politikos et al. (2015) coupled a DEB model with a hydrodynamic model to infer the influence of oceanographic conditions on the reproduction of anchovy (Engraulis encrasicolus). Energy allocation has also been tracked through field measurements of individuals. For example, Brosset et al. (in this symposium) illustrated how in situ measurements of relative condition factors of 43000 individuals can be correlated to environmental conditions to inform on the energy allocation strategy of anchovy.

Studying species adaptations to climate change is an active field of research, yet genetic approaches remain marginal at present in fisheries science. Levels of population differentiation, as measured by the fixation index (Fst) and effective population size estimates are challenging our traditional demographic views. Bonhomme (in this symposium) put forward some of these concepts and demonstrated the existence of two populations of anchovy, a coastal and an offshore one, linked by gene fluxes. Demo-genetic models that combine mechanistic population dynamics and evolutionary processes have been developed to explore the ability of species to adapt to climate change (e.g., Piou and Prévost 2012; Mateo et al., in this symposium). Similarly, models coupling dispersion modules with climatic scenarios have been developed to predict the ability of species to adapt their distribution areas in a context of climate change (Rougier et al. 2014). Statistical approaches have also been used to explore phenological adaptations to climate change (Chevillot et al., in this symposium).

\subsection{The revolution of individual tracking methods}

At the lowest organizational level, individual tracking methods and the analysis of individual behaviors are making remarkable progress. The technological developments of tracking methods during the 1990s have opened new opportunities for behavioral ecology (Cagnacci et al. 2010; Jonsen et al. 2003). Meanwhile, the new paradigms in movement ecology proposed by Nathan et al. (2008) combined with the development of appropriate analytical methods such as statespace models (Jonsen et al. 2013; Joo et al. 2013) or segmentation tools (Nams 2014), have revolutionized the study of individual movements. Movement analysis can address several types of questions (Nathan et al. 2008): why organisms move, how they move, where and when they move, how the environment influences these movements, and how these components interact. Movement analyses can provide important insights into the life cycle of populations (de Pontual et al. 2015, this symposium; and during this symposium Leopold et al. for reef fish in Vanuatu or Woillez et al. for the European sea bass), inform on key aspects of species interactions (see Bertrand et al., this symposium, on the tracking of seabirds and marine mammals, complemented with field observations in Passuni et al., this symposium) and management (Barton et al. 2015). Individual tracking methods have not only been applied to animals, but also to humans and fishing vessels. The development of Vessel Monitoring Systems has enabled fine tracking of fishing vessels resulting in a better understanding of fishers' fishing behavior, and quantification of fishing effort (Bez et al. 2011; Gloaguen et al. 2015; Vermard et al. 2010; Maufroy et al., this symposium). This can also provide valuable information on the spatial distribution of target species (Walker 2010, this symposium; Gloaguen et al. 2016). Individual vessel tracking through the analysis of onboard observations or log-books can inform on interactions between fishermen and exploited resources (Bourdaud et al., this symposium; Escalle et al., this symposium; Conte et al., this symposium; Robert et al., this symposium).

\subsection{Different levels of complexity to address multifaceted anthropogenic pressures}

Another important ecological question debated during this symposium and related to some extent to the question of scale discussed earlier, is the issue of complexity and more specifically of model complexity. Simple models are generally considered robust and more generic. On the other hand, complex models are considered more detailed and realistic, but more sensitive and case-specific. While simple models may provide biased estimates, more complex models tend to increase estimation uncertainty (Costanza and Sklar 1985; Hâkanson 1995; Burnham and Anderson 2002). The development of complex models used to be constrained by computational power. For a long time, modellers have sought the simplest model to address their question, honoring the so-called parsimony principle (Box and Jenkins 1970). Various criteria have been proposed to seek the best model, i.e. the best trade-off between detail, simplicity, data availability and ease of communication (see for example the discussion in Cotter et al. (2004) about complexity and stock assessment models and Lehuta et al. 2016).

The strategy of looking only for a single "best model" is now changing. In view of the uncertainty related to model selection, the development of multi-model inference methods in the early 2000s has enabled scientists to combine results from different models with different levels of complexity (Hoeting et al. 1999; Burnham and Anderson 2002). The already mentioned end-to-end models which are based on coupling several 
simple models describing elementary processes, or integrated models which couple different models describing various components of a system, are alternative ways to address questions. In a recent paper Evans et al. (2013) argued that simple and complex models can be linked together to produce broad-scale and predictive understanding of biological systems. Combining models that have different levels of complexity appears to be an alternative strategy to benefit from the advantages of both types of models. Working with a large range of models from the simplest to the most complex is not a utopia in practice. This is because modern computational power coupled with constantly increasing data quantities enables parameterization and exploration (Iooss, this symposium) of even highly complex models. However, as debated during a dedicated session of the symposium, the next challenge is to develop frameworks to guide the combination of approaches, and how to use this combination to inform management, especially when dealing with situations in which different models provide contradictory results.

\subsection{How should scientists address uncertainty?}

The debate about model complexity raises the question about uncertainty which was debated during a specific session during the symposium (Bez et al., this symposium). Uncertainty arises from several sources: uncertainty in data, uncertainty in knowledge but also unknown uncertainties (Chow and Sarin 2002; O'Hagan 2004). There is a long history of dealing with these uncertainties. For example, statistical confidence intervals and sensitivity analyses (Kleijnen 1987; Faivre et al. 2013) aim to quantify the impacts of uncertainties on outputs while multi-inference modeling and management strategy evaluation (Smith et al. 1999; Bunnefeld et al. 2011) aim to enhance the robustness of outputs to various sources of uncertainty. These approaches all address known sources of uncertainty but can hardly deal with "unknown unknowns". Interestingly, rather than dealing with uncertainty, other modeling strategies have proposed focusing on the few certainties (Mullon et al. 2009; Planque et al. 2014, this symposium), eliminating impossible trajectories whilst considering all other trajectories, including "known unknowns" (sources of uncertainty we are aware of) and "unknown unknowns" (sources of uncertainty we are not even aware of).

These methodological developments have greatly enhanced scientific management recommendations and form an integral part of scientific work, which must be objective and transparent. Probabilistic frameworks are now widely used by scientists and translated by managers when fixing objectives. However, uncertainty cannot be restricted to a statistical or mathematical issue but raises questions about how these uncertainties should be communicated, how they are understood and how they are used by stakeholders and managers. A session was dedicated to this question during the symposium. While the "precautionary approach" states that actions should not be delayed because of uncertainties, uncertainties can be used by lobbies to cast doubt and delay actions, which is called "agnotology" (Proctor and Schiebinger 2008; Brandt 2009; Latour 2012). In the Bluefin tuna example (Fromentin et al. 2014, this symposium), while uncertainties had been used by stakeholders to delay conservation measures in the Mediterranean Sea, they were also used by NGOs to promote these measures.

Moreover, scientific uncertainty is not synonymous with management uncertainty. First, management uncertainty relates to decisions not only on domain-specific probabilistic questions. Management decisions have important socioeconomic consequences, sometimes much more uncertain than the ecological uncertainty (Hall 2002; Faulkner et al. 2007; Nollet and De Gelder 2000). Second, the uncertainty measures provided by scientists are often related to uncertainty around a mean state while managers are generally more interested in risks related to the occurrence of extreme events which are not always well addressed by scientists. As an example, managers may be more interested in the extinction probability of a species (binary consideration) while scientific models will often estimate the probability that the expected (i.e. mean) abundance stays at a given level and these models are not necessarily appropriate for extreme situations. This discrepancy in the type of uncertainty considered is even more dramatic given that the scientific probabilistic framework is not "measurable" in the real world. In the real world, an event occurs or does not occur, and there is no way to validate a scientific statement saying that the event will occur with $x \%$ probability.

In this context, the question is not to ponder on whether scientists should hide uncertainties, but rather consider how they should communicate them, especially when providing advice to managers.

\subsection{A multidimensional science}

The use and understanding of uncertainty by managers and stakeholders is not only an ecological issue, but also a political and sociological one. This is one example amongst others that demonstrates the potential insights from social sciences for achieving sustainable management, i.e. management that preserves the sustainability of the resource and of all the associated goods and services. As mentioned above socioeconomical aspects are still poorly considered in the implementation of the EAFM. In a recent review of the restoration of aquatic ecosystems, Wortley (2013) found that the socio-economic context had been considered in a very limited number of restoration programs. Further, mixed results of these restoration programs can often be explained by sociopolitical or economic barriers (Pahl-Wostl et al. 2013). On the other hand, several examples illustrate that the involvement of stakeholders can lead to unexpected effective results. The example of the transformation of the Scottish fisheries is very instructive: the unexpected mobilization of stakeholders lead to a deep transformation of the whole industry towards more sustainability (Carter 2014, this symposium), an objective that the European Common Fisheries Policy had failed to achieve. During this symposium, the relevance of multidimensional monitoring was illustrated by the example of the Iroise Marine Natural Park. For this park a multidimensional and co-constructed scoreboard (Gamp et al., this symposium), an ecosystem services assessment (Vanhoutte-Brunier et al., this symposium), and consideration of anthropological aspects (Mariat-Roy et al., this symposium) were presented. Tissière et al. (this symposium) illustrated the potential 
of a geoprospective to co-construct a shared view of the future by several stakeholders.

Bio-economic models have been developed for a long time. However they are not yet used routinely to inform management. The methods proposed by Gascuel et al. (2012) may be a first step towards more integrated assessment and management of fisheries, taking into account socio-economic and ecological quantitative indicators of fisheries. However, there are currently no tools or frameworks that could incorporate qualitative anthropological, social or political criteria. Moreover, the context in which the exploitation of aquatic ecosystems takes place is not static and evolves rapidly, especially with global change. This moving context is a source of barriers or opportunities that are hardly predictable; what appears impossible today may be possible tomorrow. The uncertainty around the Bluefin tuna status was a barrier to conservation measures before being an incentive. It is therefore clear that integrating constructivist approaches can help both science and management to understand the objectives and strategies of different stakeholders, to highlight barriers or opportunities and to redraw scientific/political boundaries (Carter 2013).

\section{Conclusion}

The title of this paper calls for a protean science to address the degradation of aquatic ecosystems. By protean science we mean a multifaceted multidimensional science that works at all scales and all levels of complexity. A science that is aware of uncertainty, remains organized and integrates this complexity and that is able to adapt quickly to new challenges. Such a protean science is required to address the complexity of the functioning of socio-ecosystems which still conceals many mysteries (see for example Husson et al., this symposium) and the complexity of anthropogenic pressures that are also multiple, multidimensional and constantly changing. The upcoming challenge is most likely to build new frameworks that gain the greatest benefit from this protean science to achieve effective sustainability of exploited aquatic ecosystems.

Acknowledgements. The symposium was organized with the financial support of Ifremer, IRD, Agrocampus Ouest and la Région Languedoc-Roussillon. We would like to thank all speakers, and especially the invited speakers (A. Bertand, V. Maris, B. Planque, F. Bonhomme, P. Fréon, A. Avadi and B. Ioos), the Aquarium Mare Nostrum (Montpellier, France) staff for hosting this symposium, and all persons involved in the organization, with special thanks to Catherine Le Penven. Finally, we are very grateful to D. Caitriona Carter for her help in writing this article, and to D. Verena Trenkel and an anonymous referee for their valuable suggestions and comments when revising this paper.

\section{References}

(For references mentioned as "this symposium" power point presentations are available at http://association-francaisehalieutique.fr/conferences/)

Abdou K., Halouani G., Hattab T., Romdhane M.S., Lasrma F. Ben Rais, Le Loc'h F. 2016, Exploring the potential effects of marine protected areas on the ecosystem structure of the Gulf of Gabes using the Ecospace model. Aquat. Living Res. 29, 202.
Avadí A., Fréon P., 2013, Life cycle assessment of fisheries: A review for fisheries scientists and managers. Fish. Res. 143, 21-38.

Barange M., Cheung W.W.L., Merino G., Perry R.I., 2010, Modelling the potential impacts of climate change and human activities on the sustainability of marine resources. Curr. Opin. Environ. Sustain. 2, 326-333.

Barton P.S., Lentini P.E., Alacs E., Bau S., Buckley Y.M., Burns E.L., Driscoll D.A., Guja L.K., Kujala H., Lahoz-Monfort J.J., Mortelliti A., Nathan R., Rowe R., Smith A.L., 2015, Guidelines for Using Movement Science to Inform Biodiversity Policy. Environ. Manage. 56, 791-801.

Bertrand A., Chaigneau A., Peraltilla S., Ledesma J., Graco M., Monetti F., Chavez F.P., 2011, Oxygen: A Fundamental Property Regulating Pelagic Ecosystem Structure in the Coastal Southeastern Tropical Pacific. PLoS ONE 6, e29558.

Bez N., Walker E., Gaertner D., Rivoirard J., Gaspar P., 2011, Fishing activity of tuna purse seiners estimated from vessel monitoring system (VMS) data. Can. J. Fish. Aquat. Sci. 68, 1998-2010.

Box G., Jenkins G.M., 1970, Time-Series Analysis: Forecasting and Control. Holden-Day.

Brandt A., 2009, The Cigarette Century: The Rise, Fall, and Deadly Persistence of the Product That Defined America. First Reprint edition, Basic Books.

Bunnefeld N., Hoshino E., Milner-Gulland E.J., 2011, Management strategy evaluation: a powerful tool for conservation? Trends Ecol. Evol. 26, 441-447.

Burnham K.P., Anderson D.R., 2002, Model Selection and Multimodel Inference: A Practical Information Theoretic Approach. Springer.

Cagnacci F., Boitani L., Powell R.A., Boyce M.S., 2010, Animal ecology meets GPS-based radiotelemetry: a perfect storm of opportunities and challenges. Philos. Trans. R. Soc. B Biol. Sci. 365, $2157-2162$.

Carter C.A., 2013, Constructing sustainability in EU fisheries: Redrawing the boundary between science and politics? Environ. Sci. Policy 30, 26-35.

Carter C., 2014, The transformation of Scottish fisheries: Sustainable interdependence from "net to plate". Mar. Policy 44, 131-138.

Chave J., 2013, The problem of pattern and scale in ecology: what have we learned in 20 years? Ecol. Lett. 16, 4-16.

Cheung W.W., Lam V.W., Sarmiento J.L., Kearney K., Watson R.E.G., Zeller D., Pauly D., 2010, Large-scale redistribution of maximum fisheries catch potential in the global ocean under climate change. Glob. Change Biol. 16, 24-35.

Chevillot X., Pierre. M, Rigaud A., Drouineau H., Chaalali A., Sautour B., Lobry J., 2016. Abrupt shifts in the Gironde fish community: an indicator of ecological changes in an estuarine ecosystem. Mar. Ecol. Prog. Ser. 549, 137-151.

Chow C.C., Sarin R.K., 2002, Known, unknown, and unknowable uncertainties. Theory Decis. 52, 127-138.

Costanza R., Sklar F.H., 1985, Articulation, accuracy and effectiveness of mathematical models: a review of freshwater wetland applications. Ecol. Model. 27, 45-68.

Cotter sA J.R., Burt L., Paxton C.G.M., Fernandez C., Buckland S.T., Pan J.X., 2004, Are stock assessment methods too complicated? Fish Fish. 5, 235-254.

de Pontual H., Ngo T.-T., Lalire M., Lazure P., Garren F., Drogou M., Woillez M., Fablet R., 2015, Understanding the spatial dynamics of European sea bass: new insights on seasonal migration patterns from electronic tagging off the coast of west Brittany. ICES Annual science conference, ICES CM 2013/O:05.

Doney S.C., Fabry V.J., Feely R.A., Kleypas J.A., 2009, Ocean acidification: the other CO2 problem. Mar. Sci. 1, 169-172. 
Evans M.R., Grimm V., Johst K., Knuuttila T., de Langhe R., Lessells C.M., Merz M., O'Malley M.A., Orzack S.H., Weisberg M., Wilkinson D.J., Wolkenhauer O., Benton T.G., 2013, Do simple models lead to generality in ecology? Trends Ecol. Evol. 28, 578-583.

Faivre R., Iooss B., Mahévas S., Makowski D., Monod H., 2013, Analyse de sensibilité et exploration de modèles. Quae.

FAO 2014, State of the World Fisheries and Aquaculture 2014. S.1., Food \& Agriculture Organization of the United Nations.

Faulkner H., Parker D., Green C., Beven K., 2007, Developing a translational discourse to communicate uncertainty in flood risk between science and the practitioner. AMBIO J. Hum. Environ. 36, 692-704.

Feely R.A., Doney S.C., Cooley S.R., 2009, Ocean acidification: present conditions and future changes in a high-CO2 world.

Froese R., Walters C., Pauly D., Winker H., Weyl O.L.F., Demirel N., Tsikliras A.C., Holt S.J., in Press, A critique of the balanced harvesting approach to fishing. ICES J. Mar. Sci. doi:10.1093/icesjms/fsv122.

Fromentin J.-M., Bonhommeau S., Arrizabalaga H., Kell L.T., 2014, The spectre of uncertainty in management of exploited fish stocks: The illustrative case of Atlantic bluefin tuna. Mar. Policy 47, 8-14.

Fulton E.A., 2010, Approaches to end-to-end ecosystem models. J. Mar. Syst. 81, 171-183.

Fulton E.A., Fuller M., Smith A., Punt A.E., 2004, Ecological indicators of the ecosystem effects of fishing: final report. CSIRO.

Garcia S.M., 2003, The Ecosystem Approach to Fisheries: Issues, Terminology, Principles, Institutional Foundations, Implementation and Outlook. PAO.

Garcia S.M., Kolding J., Rice J., Rochet M.-J., Zhou S., Arimoto T., Beyer J.E., Borges L., Bundy A., Dunn D., Fulton E.A., Hall M., Heino M., Law R., Makino M., Rijnsdorp A.D., Simard F., Smith A.D.M., 2012, Reconsidering the Consequences of Selective Fisheries. Science 335, 1045-1047.

Garcia S.M., Rice J., Charles A., 2015, Balanced harvesting in fisheries: a preliminary analysis of management implications. ICES J. Mar. Sci. J. Cons. Fsv156.

Gascuel D., Pauly D., 2009, EcoTroph: modelling marine ecosystem functioning and impact of fishing. Ecol. Model. 220, 2885-2898.

Gascuel D., Bez N., Forest A., Guillotreau P., Laloë F., Lobry J., Mahévas S., Mesnil B., Rivot E., Rochette S., Trenkel V., 2011, A future for marine fisheries in Europe (Manifesto of the Association Française d'Halieumétrie). Fish. Res. 109, 1-6.

Gascuel D., Merino G., Döring R., Druon J.N., Goti L., Guénette S., Macher C., Soma K., Travers-Trolet M., Mackinson S., 2012, Towards the implementation of an integrated ecosystem fleet-based management of European fisheries. Mar. Policy 36, 1022-1032.

Gattuso J.-P., Magnan A., Billé R., Cheung W.W.L., Howes E.L., Joos F., Allemand D., Bopp L., Cooley S.R., Eakin C.M., HoeghGuldberg O., Kelly R.P., Pörtner H.-O., Rogers A.D., Baxter J.M., Laffoley D., Osborn D., Rankovic A., Rochette J., Sumaila U.R., Treyer S., Turley C., 2015, Contrasting futures for ocean and society from different anthropogenic $\mathrm{CO} 2$ emissions scenarios. Science 349, aac4722.

Gloaguen P., Mahévas S., Rivot E., Woillez M., Guitton J., Vermard Y., Etienne M.-P., 2015, An autoregressive model to describe fishing vessel movement and activity. Environmetrics 26, 17-28.

Gloaguen P., Woillez M., Mahévas S., Vermard Y. Rivot E., 2016, Is speed through water a better proxy for fishing activities than speed over ground? Aquat. Living Res. 29, 210.
Guesnet V., Lassalle G., Chaalali A., Kearney K., Saint-Béat B., Karimi B., Grami B., Tecchio S., Niquil N., Lobry J., 2015, Incorporating food-web parameter uncertainty into Ecopathderived ecological network indicators. Ecol. Model. 313, 29-40.

Hâkanson L., 1995, Optimal size of predictive model. Ecol Model. 78, 195-204.

Hall J.W., 2002, A contingency approach to choice. Civ. Eng. Syst. $19,87-118$.

Hering D., Borja A., Carstensen J., Carvalho L., Elliott M., Feld C., Heiskanen A.-S., Johnson R., Moe J., Pont D., Solheim A., de Bund W., 2010, The European Water Framework Directive at the age of 10: A critical review of the achievements with recommendations for the future. Sci. Total Env. 408, 4007-4019.

Hoeting J.A., Madigan D., Raftery A.E., Volinsky C.T., 1999, Bayesian model averaging: a tutorial. Stat. Sci. 382-401.

Jonsen I.D., Myers R.A., Flemming J.M., 2003, Meta-analysis of animal movement using state-space models. Ecology 84, 3055-3063.

Jonsen I.D., Basson M., Bestley S., Bravington M.V., Patterson T.A., Pedersen M.W., Thomson R., Thygesen U.H., Wotherspoon S.J., 2013, State-space models for bio-loggers: A methodological road map. Deep Sea Res. Part II 88-89, 34-46.

Joo R., Bertrand S., Tam J., Fablet R., 2013, Hidden Markov Models: The Best Models for Forager Movements? PLoS ONE 8, e71246.

Kleijnen J.P.C., 1987, Statistical tools for simulation practitioners. Marcel Dekker Inc. Pub, New York.

Kooijman S.A.L.M., 2000. Dynamic Energy and Mass Budgets in Biological Systems. Cambridge University Press.

Latour B., 2012, Que la bataille se livre au moins à armes égales. In: Zaccai E., Gemenne F., Decroly J.M. (Eds) Controverses climatiques, sciences et politique. Presses de Sciences Po, pp. 1-7.

Lehuta S., Girardin R., Mahévas S., Travers-Trolet M., Vermard V., 2016, Reconciling complex models and fisheries advice: Practical examples and leads. Aquat. Living Res. 29, 208.

Levin S.A., 1992, The Problem of Pattern and Scale in Ecology: The Robert H. MacArthur Award Lecture. Ecology 73, 1943-1967.

Lotze H.K., Lenihan H.S., Bourque B.J., Bradbury R.H., Cooke R.G., Kay M.C., Kidwell S.M., Kirby M.X., Peterson C.H., Jackson J.B., 2006, Depletion, degradation, and recovery potential of estuaries and coastal seas. Science 312, 1806-1809.

Marandel F., Lorance P., Trenkel V.M., 2016, A Bayesian state-space model to estimate population biomass with catch and limited survey data: application to the thornback ray (Raja clavata) in the Bay of Biscay. Aquat. Living Res. 29, 209.

Maris V., 2014, Nature à vendre. Quae Versailles.

Millennium Ecosystem Assessment, 2005, Ecosystems and human well-being. Island Press Washington, DC.

Mullon C., Fréon P., Cury P., Shannon L., Roy C., 2009, A minimal model of the variability of marine ecosystems. Fish Fish. 10, 115-131.

Nams V.O., 2014, Combining animal movements and behavioural data to detect behavioural states. Ecol. Lett. 17, 1228-1237.

Nathan R., Getz W.M., Revilla E., Holyoak M., Kadmon R., Saltz D., Smouse P.E., 2008, A movement ecology paradigm for unifying organismal movement research. Proc. Natl. Acad. Sci. 105, 19052-19059.

Nollet L.M., De Gelder L.S., 2000, Handbook of water analysis. CRC Press.

O'Hagan T., 2004, Dicing with the unknown. Significance 1, 132-133. 
Orr J.C., Fabry V.J., Aumont O., Bopp L., Doney S.C., Feely R.A., Gnanadesikan A., Gruber N., Ishida A., Joos F., Key R.M., Lindsay K., Maier-Reimer E., Matear R., Monfray P., Mouchet A., Najjar R.G., Plattner G.-K., Rodgers K.B., Sabine C.L., Sarmiento J.L., Schlitzer R., Slater R.D., Totterdell I.J., Weirig M.-F., Yamanaka Y., Yool A., 2005, Anthropogenic ocean acidification over the twenty-first century and its impact on calcifying organisms. Nature 437, 681-686.

Pahl-Wostl C., Arthington A., Bogardi J., Bunn S.E., Hoff H., Lebel L., Nikitina E., Palmer M., Poff L.N., Richards K., others, 2013, Environmental flows and water governance: managing sustainable water uses. Curr. Opin. Environ. Sustain. 5, 341-351.

Pauly D., Christensen V., Walters C., 2000, Ecopath, Ecosim, and Ecospace as tools for evaluating ecosystem impact of fisheries. ICES J. Mar. Sci. 57, 697-706.

Piou C., Prévost E., 2012, A demo-genetic individual-based model for Atlantic salmon populations: Model structure, parameterization and sensitivity. Ecol. Model. 231, 37-52.

Planque B., Lindstrøm U., Subbey S., 2014, Non-Deterministic Modelling of Food-Web Dynamics. PLoS ONE 9, e108243.

Politikos D.V., Huret M., Petitgas P., 2015, A coupled movement and bioenergetics model to explore the spawning migration of anchovy in the Bay of Biscay. Ecol. Model. 313, 212-222.

Postel S., Richter B., 2003, Rivers for life: managing water for people and nature. Island Press.

Prato G., Gascuel D., Valls A., Francour P., 2014, Balancing complexity and feasibility in Mediterranean coastal food-web models: uncertainty and constraints. Mar. Ecol. Prog. Ser. 512, 71-88.

Proctor R., Schiebinger L., 2008, Agnotology: The Making and Unmaking of Ignorance. Stanford, Calif, Stanford University Press.
Rose K.A., Allen J.I., Artioli Y., Barange M., Blackford J., Carlotti F., Cropp R., Daewel U., Edwards K., Flynn K., others, 2010, Endto-end models for the analysis of marine ecosystems: challenges, issues, and next steps. Mar. Coast. Fish. 2, 115-130.

Rougier T., Drouineau H., Dumoulin N., Faure T., Deffuant G., Rochard E., Lambert P., 2014, The GR3D model, a tool to explore the Global Repositioning Dynamics of Diadromous fish Distribution. Ecol. Model. 283, 31-44.

Shin Y.-J., Cury P., 2004, Using an individual-based model of fish assemblages to study the response of size spectra to changes in fishing. Can. J. Fish. Aquat. Sci. 61, 414-431.

Smith A.D.M., Sainsbury K.J., Stevens R.A., 1999, Implementing effective fisheries-management systems - management strategy evaluation and the Australian partnership approach. ICES J. Mar. Sci. J. Cons. 56, 967-979.

Vermard Y., Rivot E., Mahévas S., Marchal P., Gascuel D., 2010, Identifying fishing trip behaviour and estimating fishing effort from VMS data using Bayesian Hidden Markov Models. Ecol. Model. 221, 1757-1769.

Walker E., 2010, De la trajectoire des prédateurs à la cartographie de leurs proies: estimation spatiale de l'activité des senneurs et des thonidés dans l'Océan indien. Paris, ENMP.

Worm B., Barbier E.B., Beaumont N., Duffy J.E., Folke C., Halpern B.S., Jackson J.B., Lotze H.K., Micheli F., Palumbi S.R., others, 2006, Impacts of biodiversity loss on ocean ecosystem services. Science 314, 787-790.

Wortley L., Hero J.-M., Howes M., 2013, Evaluating ecological restoration success: a review of the literature. Restor. Ecol. 21, 537-543. 